\title{
建築工事の工程計画における結合率を導入したネットワーク手法 NETWORK METHOD USING CONNECTING RATIO IN CONSTRUCTION SCHEDULING
}

\author{
土橋 稔 美*, 正村 芳 久**, 吉田知洋*** \\ Toshimi DOBASHI, Yoshihisa MASAMURA and Tomohiro YOSHIDA
}

\begin{abstract}
The network method of construction planning and scheduling is introduced, which is being long-continued. The network method decomposes construction work for the activity, and gives the activity sequence. However, the conventional network method is not suitable for the expression of the parallel activity which can start the succession activity in point of time when the precedence activity is un- end. This report showed the formula of network expression which uses connecting ratio in the activity sequence for the circle type network, its time calculation, and its applications. In the network method, a proposed method not only can express the conventional activity sequence, but enables expression of parallel activity.
\end{abstract}

Keywords: construction scheduling, network method, PERT, activity sequence, parallel activity 工程計画, ネットワーク手法, PERT, 順序関係, 並行作業

1. はじめに

建築工事の工程計画に数理的な方法に基づくネットワーク手法が 導入されて久しく, 数多くの研究やシステム開発が行われてきた。 日本建築学会においても,ネットワーク手法に関する指針を 1968 年に発行している》。指針では, 工程計画が手順計画と日程計画から. なり注 1), 手順計画は「目標達成に必要な作業·作業順序·所要時間 および資源などをきめる計画」，日程計画は「指定工期・手持資源 などの制約のもとで計画達成に必要な作業の日程をきめる計画」で あるとしている。指針で示されたネットワーク手法の活用は主に手 書きのネットワーク工程図に基づく検討・立案であったが, 近年, 工程計画用のソフトウェアの導入が進みつつある。実務において, 特にコンピュータ利用が進みつつあるのは日程計画であり, PERT による日程計算や労務・機械の山積計算, ネットワーク工程図の作 成である。

ネットワーク手法は, 建築工事を作業に分解し, 作業間に順序関 係（または先行・後続関係）をつけることを基本とする。作業間の 順序関係は，後続作業の開始を先行作業の終了後とする FS(Finish-to-Start)タイプが最も使用される。建築工事の作業には FSタイプ以外に, 作業間に先行·後続関係があり, かつ先行作業が 未終了の時点で後続作業を開始できる順序関係, すなわち本報告に
て並行作業と呼ぶ関係も存在する。しかし, FS タイプは並行作業の 表現に適していない。したがって，作業の実態に即した並行作業も 表せるネットワーク手法, すなわちネットワーク表現のみならず日 程計算の方法も求められる。

\section{2. 既往の研究と本研究の目的}

\section{1. 既往の研究}

嘉納による工程管理の手法や技術に関する変遷の分析から，これ までに数多くの研究開発が行われてきたことがわかるす。その中で, 並行作業を表すためにネットワーク手法を拡張した既往の研究開発 を以下に示す。

(1)一般的な 4 タイプ (図-1-(1))

図ー 1-(1)に作業間の順序関係として一般的に採用されている4 タイプを示す。このタイプでは，作業の開始または終了により作業 間に順序関係を付けるため, 「先行作業が $50 \%$ 経過後に; 後続作業 が追いかける」といった並行作業を表せない。一般的な 4 タイプで 並行作業を表現するには作業を分割して表現する必要があった。 (2)嘉納の分岥ネットワーク（図ー1-(2)）

嘉納は並行作業を表せるようにするため，アロー型ネットワーク 注2)においてアロー（矢線）の途中から別のアローを分岐させる分
* 鹿島技術研究所 主任研究員. 工修

** 鹿島技術研究所 主管研究員

*** 鹿島東京支店.工修
Senior Research Engineer, Kajima Technical Research Institute, M. Eng.

Chief Research Engineer, Kajima Technical Research Institute

Engineer, Kajima Tokyo Branch, M. Eng. 
岐ネットワークの表現方法とその日程計算を定式化している ${ }^{3)}$ 。ア ローの分岐点（または合流点）は，並行する作業間で設定したリー ドタイムにより求められる。建築工事における複雑な工程を表現す るには分岐ネットワークの採用が必要であるとしている。

(3)森口・若木のモデル（図-1-(3)）

森口・若木は嘉納の分岐ネットワークに，「後続作業が先行作業 に重複して作業を行う日数」をタブル日数として導入し, 並行作業 を表すモデルを提案している ${ }^{4)}$ 。タブル日数は，作業の規模（作業 量) で場合分けした計算式を用い, 各計算式の算出結果の最小値と している。ダフル日数の考え方を示した図ー1-(3)はサークル型ネ ットワーク注 3)による表現であるが，日程計算上のモデルは募納の 分岐ネットワークが採用されている。

以上のように，既往の研究における並行作業の表現はアロー型ネ ットワークを対象にしたものである。その特徽は，1)アローの分岐 と合流，2)リードタイムによるアローの分岐点の設定にある。しか し，グラフ理論に基づくネットワーク手法では，アローの途中から 別のアローの分䁌や合流を理論的に許していない。

\section{2. 本研究の目的}

本研究は，並行作業を表現する上でグラフ理論的にも問題のない ネットワーク手法の構築を目的としたものであり，分㞳ネットワー

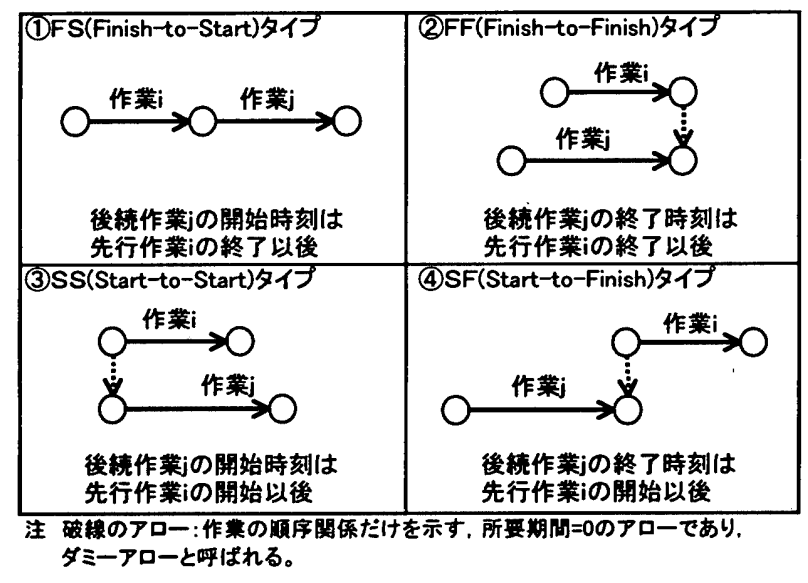

(1)一般的な4タイプ

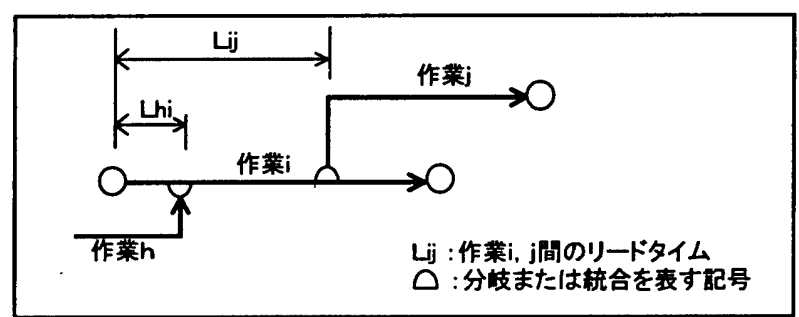

(2) 重納の分䣫ネットワーク

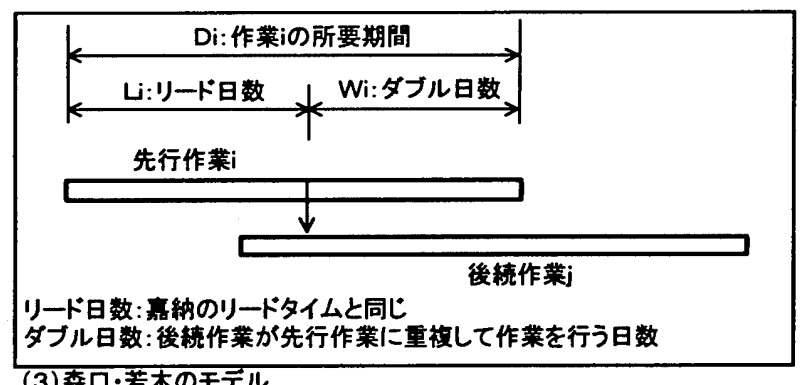

(3) 森口・若木のモデル

图-1 既往の作菜間の順序関係の表し方
クと異なる基礎的手法を提供するものである。

本報告におけるネットワーク表現の特徵は, サークル型ネットワ ークを対象にして作業間の順序関係に結合率を導入することによ ク，並行作業の表現を可能としたことである。本報告ではそのネッ トワーク表現と日程計算の方法を示すとともに ${ }^{5)}$, 詳細工程計画と 作業計画への適用例を示す。

3. 桔合率を導入したネットワーク表現とその日程計莮の定式化

3.1. 作菜間の順序關係に合率を導入したネットワーク表現 (1)結合率を導入した作業間の順序関係

図ー 2 に示すように，結合率は先行作業 $\mathrm{i}$ と後続作業 $\mathrm{j}$ の各々の 所要期間に対する作業が経過した割合(\%)であり，先行作業 $\mathrm{i}$ の経過 した割合を先行側の結合率 PRij(\%), 後続作業 j の経過した割合を 後続側の結合率 SRij(\%)と定義する。この結合率を作業間の順序関 係に導入すると, 後続作業 j の所要期間 Dj が SRij(\%)だけ経過する 時刻 TSRij は，先行作業 i の所要期間 Di が PRij(\%)だけ経過する 時刻 TPRij 以後となる。したがって, TPRij と TSRij の関係は式(1) となる注4)。

TSRij $\geqq$ TPRij

(2)ネットワーク表現の規則

図ー2に示したネットワーク表現の規則は次の 2 つである。

(1)ネットワーク表現はサークル型ネットワークであり，ノードで あるバーの長さは作業の所要期間を表す。

(2)作業の順序関係を示すアローは結合率により，アローの始端と なる先行側の接続点と終端となる後続側の接続点を結ぶ。

以上の規則は，作業を表すバーがノードであるため，ノードのど の位置からアローを発生させてもグラフ理論上, 問題ない。

3.2. 桔合事を噵入したネットワーク表現の特畧

(1)分岐ネットワークとの違い

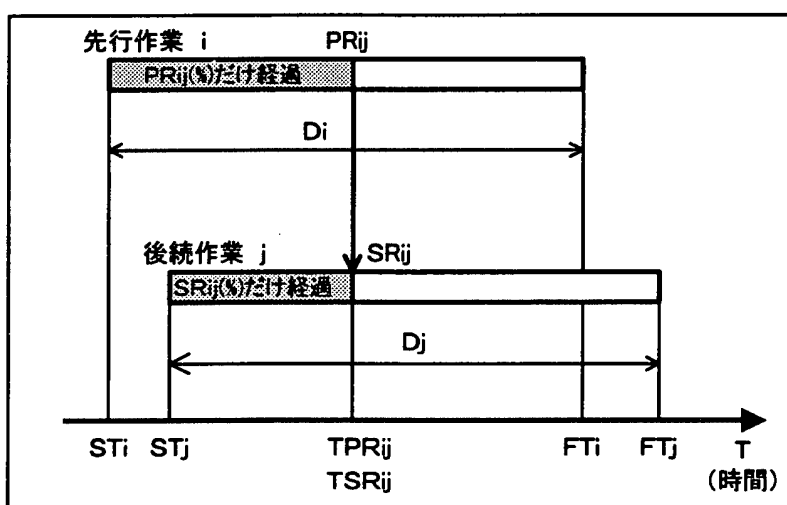

四号

$\mathrm{i}, \mathrm{j}$ : 作業

$D i, D j$ : 作業i, jの所要期間

$S T i, S T \mathrm{j}$ : 作業i, jの開始時刻

$F T i, F T$ : 作業i, jの終了時刻

PRij: 作業i, j間での先行側の結合率(

SRij: 作業i, j間での後続側の結合率(

TPRij : 先行作業が結合事PRijだけ経過する時刻

$T S R i j:$ 後続作業が結合率SRij†゙け経過する時刻

なお, $0 \leqq P R i j . ~ S R i j \leqq 100$ 
分岐ネットワークとの違いはネットワーク図の表現形式と並行 作業の表現方法であり，具体的には以下に示す 2 点である。

(1)ネットワーク図の表現形式は，分岐ネットワークがアロー型ネ ットワークを採用しているのに対し，本手法がサークル型ネッ トワークを採用している。

(2)並行作業の表現は，分岐ネットワークがリードタイムという時 間で与えるのに対し，本手法が結合率という割合で与える。 (2)利用頻度の高い並行作業の表現

結合率を利用した並行作業の表現において，先行側と後続側の結 合率がともに，0より大きく 100 末満となる場合は考えにくい。利 用頻度の高い並行作業の表現は先行作業または後続作業の一方を 基準とした結合率の設定であり，以下に示す 2 方式が考えられる。

(1)図ー3-(1)に示す先行作業を基準とした結合率の設定は, 先行 作業がある程度経過した後, '後続作業を開始する関係である。 この場合の結合率は後続側の結合率 SRij が 0 である。

(2)図ー3-(2)に示す後続作業を基準とした結合率の設定は, 後続 作業がある程度経過する時点で, 先行作業が終了する関係であ

る。この場合の結合率は先行側の結合率 PRij が 100 である。 並行作業の表現より，先行作業之後続作業がオーバラップする期 間注5)は図ー3に示すようになる。

(3)一般的な 4 タイプとその結合率による表示

結合率は, 図ー1ー-(1)の一般的な 4 タイプを包含したネットワー ク表現である。すなわち，一般的な 4 タイプの作業間の順序関係は 以下の結合率で表せ，結合率が特殊な場合となる。

(1)FS タイプ 先行側の結合率 $=100$, 後続側の結合率 $=0$

(2) FF タイプ 先行側の結合率 $=100$, 後続側の結合率 $=100$

(3)SS タイプ 先行側の結合率 $=0$, 後続側の結合率=0

(4) SF タイプ 先行側の結合率 $=0$, 後続側の結合率 $=100$

3.3. 桔合率を導入したネットワークの日程計算の定式化

(1)最早・最遅の日程計算における関係式

図一 2 より, 先行・後続関係にある作業 $\mathrm{i}$ と $\mathrm{j}$ の最早・最遅の日 程計算に用いる関係式は以下の 3 種となる。

(1)TSRij, TPRij の関係式 式(2)

$\mathrm{TSRij}=\mathrm{TPRij}+\mathrm{LAGij}$

(2)作業 i , j の開始時刻の関係式

$\mathrm{TPRij}=\mathrm{STi}+\mathrm{Di} \times \mathrm{PRij} / 100$

$\mathrm{TSRij}=\mathrm{STj}+\mathrm{Dj}_{\mathrm{j}} \times \mathrm{SRij} / 100$

(3)作業 $\mathrm{i}, \mathrm{j}$ の終了時刻の関係式

$\mathrm{TPRij}=\mathrm{FTi}-\mathrm{Di} \times(100-\mathrm{PRij}) / 100$

$\mathrm{TSRij}=\mathrm{FTj}-\mathrm{Dj} \times(100-\mathrm{SRij}) / 100$

なお，式(2)は一般的な 4 タイプにて活用される作業 $\mathrm{i}$ と jのタ ムラグ注 6) LAGij も含めた関係式にて示した。

(2)日程計算の定式化

図ー4に結合率を導入したネットワークの日程計算の式を示す。 ここに, (A)は各作業の最早の開始時刻と終了時刻を求める計算式て あり，式(2)と式(3)を使用して求める。(B)は各作業の最遅の開始時 刻と終了時刻を求める計算式であり, 式(2)と式(4)を使用して求め る。(C)は各作業のトータルフロートの計算式である。従来の日程計 算との違いは，(A)と(B)の計算式の中で先行作業と後続作業の所要 期間に，それぞれ先行側と後続側の結合率を乗じることなどである。
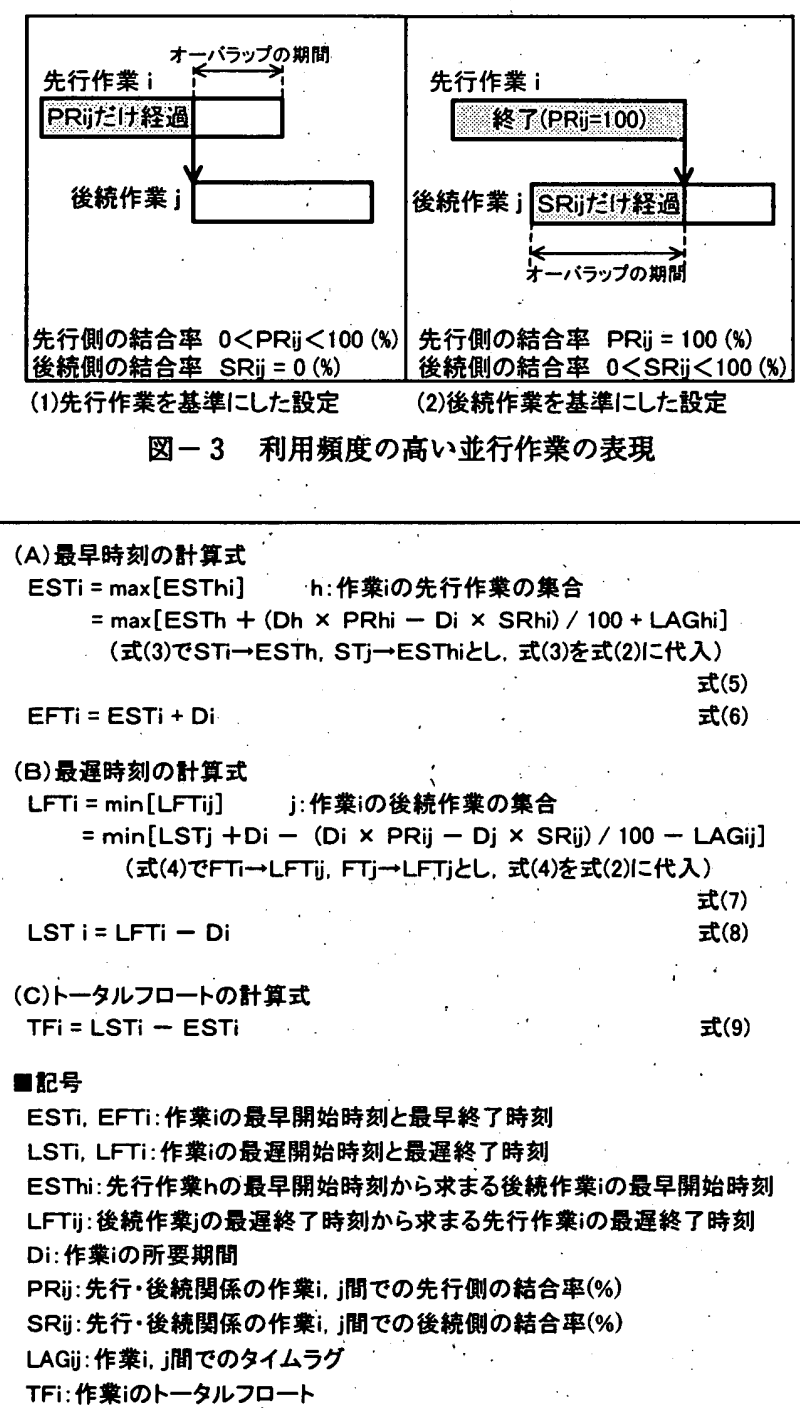

므묵

ESTi, EFTi:作莱iの最早開始時刻と最早終了時刻 LSTi， LFTi：作意iの最遅開始時刻と最荤終了時刻 ESThi : 先行作菜hの最早開始時刻から求まる後粩作業iの最早開始時刻

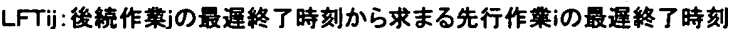
$\mathrm{Di}$ : 作萛iの所要期間

PRij: 先行·後綐関係の作菜i, j間での先行側の結合种(\%) SRij: 先行·後続関係の作菜i, j間での後続側の結合率(\%) LAGij : 作菜i, j間でのタイムラグ TFi: 作菜iのトータルフロート

図ー4 秸合染を導入したネットワークの日程䀘算の式

\section{4. 本手法の䢔用例}

\subsection{PCa 工法における建方工事の詳細工程即画への適用}

\subsection{1. 適用対象と対象建物の概要}

\section{(1)適用対象}

本適用例は，プレキャストコンクリート（以下，PCa と称す）部 材を使用したPCa 工法の建方における詳細工程計画注7)への適用を 検討したものである ${ }^{6)}$ 。適用対象の工法は柱を $\mathrm{PCa}$ ，梁を鉄骨とし た躯体 PCa 工法である。本工法の用途はショッピングセンターな どの平面的な広がりを持つ物件が多い。

本工法の建方工事は建逃げ方式 (またはびょうぶ建て方式) が探 用される。建逃げ方式は，移動式揚重機により 1 つの工区の建方を 最上階まで，または階段状に組み上げ，揚重機を次の工区に移動し て建方する方式である。本報告では揚重機を移動して同様に建方を 行う工区を建逃げ工区と称す。工区分割の結果，1つの建逃げ工区 の範囲が広い場合, 柱・梁の建方と床板敷込みの順序関係のように， 作業間に先行・後続関係があり, かつ先行作業がある程度経過した ら後続作業が開始できる場合がある。その並行作業の表現に結合率 を適用した。 
(2)対象建物と工区分割の結果

対象とした建物は，延床面積が約 4 万 7 千 $\mathrm{m}^{2}$ ，地下 1 階，地上 4 階のショッピングセンターである。図ー 5 に建方工事の工区分割結 果を示す。分割結果は揚重機毎にI工区とII区に，それぞれはさ らに複数の建逃げ工区へ分割されている。

4.1.2. 建方工程における並行作業のモテル化

(1)単位工区毎の作業で表した建逃げ工区の建方工程

図ー6に建逃げ工区 A-3 の建方工程を示す。図ー6-(1)は建逃げ 工区を単位工区へ分割し，単位工区毎の作業で表した建方工程であ る。ここで, 単位工区は作業の区切りがよい 1 日単位を基本とする 工区であり，建逃げ工区 A-3 の単位工区数は 2 である。建方工程に 含まれる作業は 3 種類であり，作業毎にその内容を以下に示す。

(1)建方作業は PCa 柱と鉄骨梁の建方だけでなく，柱と梁の高力 ボルト本締め（以下, HTB 本締めと称す）を含む作業であり，

同一階の単位工区を連続して行った後，上階の建方作業を行う。

(2)デッキプレート（以下，デッキと称す）の敷込み作業は 1 つ下 の階の建方が 1 工区分だけ終了後，その工区分のデッキを敷き 达む。

(3)グラウト作業は $\mathrm{PCa}$ 柱の柱脚部におけるグラウト注入であり， 1 つ上の階の建方が 1 工区分だけ終了後に，その工区分のグラ ウトを注入する。すなわち，グラウト注入は 1 層離れており； 同一の単位工区における建方作業の開始は 2 つ下の階のグラウ ト注入後となる。

図ー6-(1)は以上の作業内容をもとに表した建方工程である。作 業間の順序関係はすべて, 先行作業が終了後, 後続作業を開始する 関係で表せる。すなわち，単位工区毎の作業で表した建方工程では 並行作業の表現を必要としない。

(2)建逃げ工区毎の作業で表した建方工程

図ー6-(2)に単位工区毎の作業を建逃げ工区毎で表した建方工 程を示す。その結果, 図下段の結合率の欄に示すように, 3 種類の 順序関係で並行作業の表現が必要になる。たとえば，先行作業であ る $\mathrm{N}$ 階建方と後続作業である $\mathrm{N}+1$ 階デッキの関係(1) 結合率の 番号(1)に示す先行作業が $50 \%$ 経過後，後続作業が開始できることを 表す。これは，単位工区毎に分かれていた作業を建逃げ工区毎に 1 つの作業で表すことにより生じたものである。

なお，3 種類の並行作業の関係はすべて図ー3-(1)の先行作業を 基準にした設定であり，先行側の結合率が $50 \%$ ，後続側の結合率が 0\%である。結合率がその值となる理由は，単位工区毎の作業が 1 日であり，建逃げ工区 A-3 の単位工区数が 2 であることによる。 4.1.3. 並行作羓を含むネットワーク表現とその日程・山積計莮 (1)日程計算用データ

図ー6ー-(2)に示したモデル化の方法により，並行作業を含むネッ トワークの日程計算用データを作成する。表ー1にデータの一部と して, 建逃げ工区 A-3 の例を示す。データは，作業とその所要期間 を示したデータ（表ー1-(1)）と作業間の順序関係を示したデー夕 (表-1-(2)) からなる。ここで, 建逃げ工区 A-3 の作業間の順序 関係は，1)並行作業とならないFS タイプ，2)先行側と後続側の結 合率をそれぞれ $50 \%$ と $0 \%$ とした並行作業，の 2 種類で表せる。 (2)ネットワーク表現と日程計算

図ー7にI 工区を対象にした建方工程のネットワーク表現を示

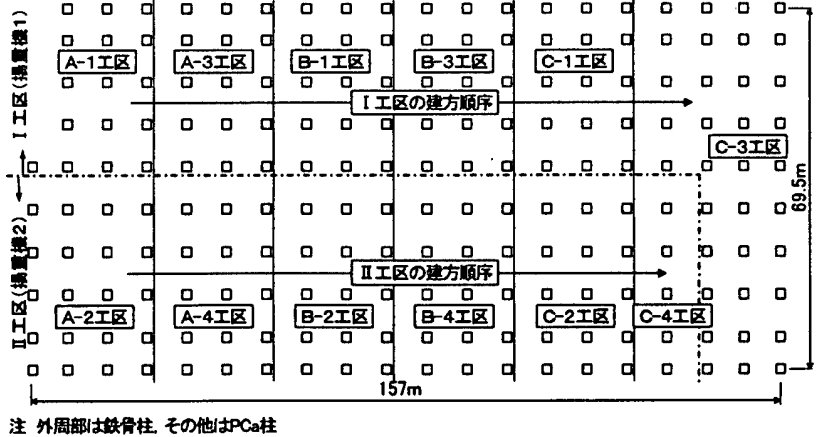

図-5 対象建物の建逃げ工区への分割桔果

\begin{tabular}{|c|c|c|c|c|c|c|c|}
\hline 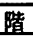 & 单位工区 & 1日 & 2日 & 3日 & 4日 & 5日 & 6日 \\
\hline & (2) & \multirow{2}{*}{\multicolumn{2}{|c|}{ 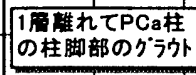 }} & & & 孚挂 & 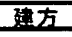 \\
\hline & (1) & & & & $\overline{7} \Rightarrow$ & 建方 & \\
\hline \multirow{2}{*}{$\mathrm{N}+1$} & (2) & & & İy抹 & 建方 & & \\
\hline & (1) & & 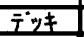 & 连方 & & & 23 201 \\
\hline & (2) & & 垔左 & & & 2 532 & \\
\hline & (1) & 建方 & & & 2331 & & \\
\hline
\end{tabular}

(1)単位エ区毎の作業で表した建方エ程

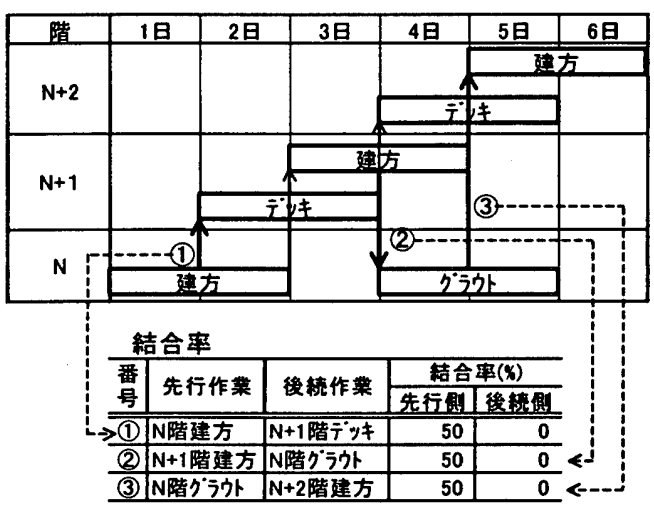

（2）建遂げエ区毎の作業で表した建方エ程

一結合事による並行作菜の表現一

注建方:PCa柱と铁每架の建方だけでなく、HTB本辞めも含む。

图ー6 桔合本による並行作番の表現 一建逃げ工区 A-3-

表ー 1 日程計算用データの一部 一建透げ工区 A-3-
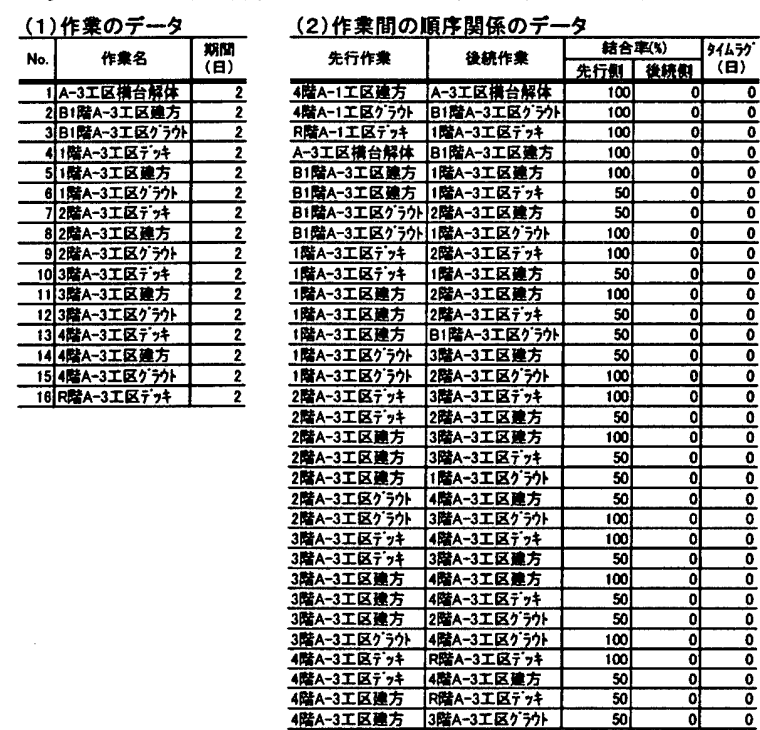


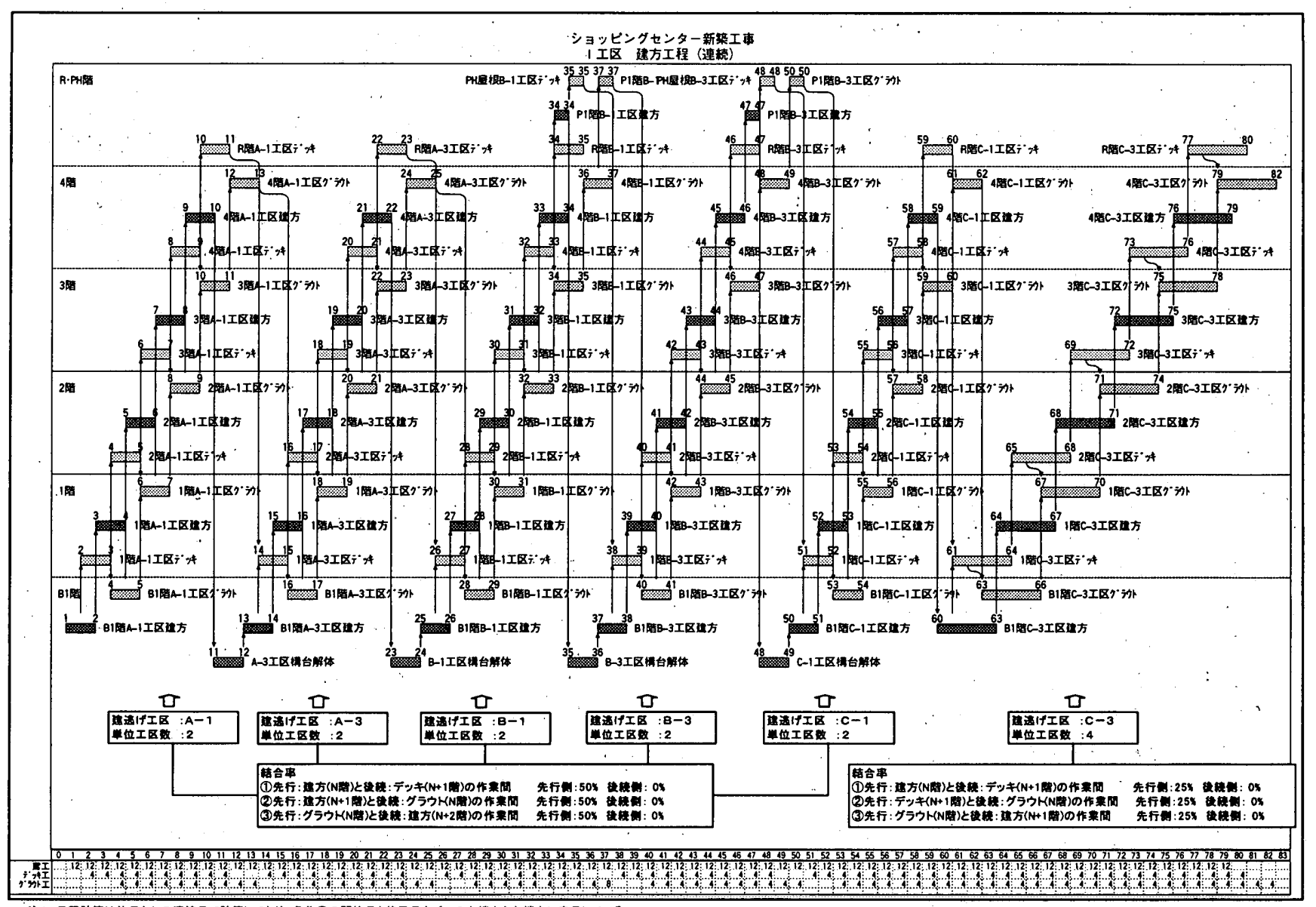

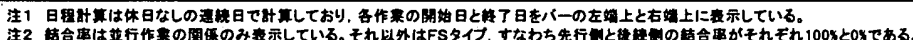

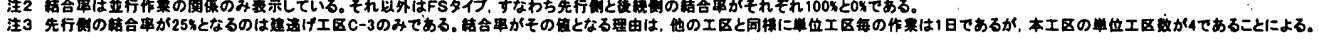

図ー7＼cjkstart並行作宷を取り入れたネットワーク工程－I工区の建方工程の最早日程による表示一

表ー2 日程計算の結果の一部－一建逃げ工区 A-3-

\begin{tabular}{|c|c|c|c|c|c|c|c|}
\hline \multirow{2}{*}{ No. } & \multirow{2}{*}{ 作菓名 } & \multicolumn{2}{|c|}{ 最早 } & \multicolumn{2}{|c|}{ 最退 } & \multirow{2}{*}{$\begin{array}{l}1-8 n \\
7 a-1\end{array}$} & \multirow{2}{*}{ C.P. } \\
\hline & & 開始日 & 蔠了日 & 開蛞日 & 舽了日 & & \\
\hline 1 & A-3工区㪹台解体 & 11 & 12 & 11 & 12 & 0 & $*$ \\
\hline 2 & B1陵A-3工区建方 & 13 & 14 & 13 & 14 & 0 & * \\
\hline 3 & B1陵A-3工区グラ外 & 16 & 17 & 16 & 17 & 0 & * \\
\hline 4 & 1陵A-3エ区デッキ & 14 & 15 & 14 & 15 & 0 & * \\
\hline 5 & 1陵A-3工区建方 & 15 & 16 & 15 & 16 & of & * \\
\hline 6 & 1陵A-3エ区グラクト & 18 & 19 & 18 & 19 & 0 & * \\
\hline 7. & 2㬗A-3エ区デゥキ & 16 & 17 & 16 & 17 & 0 & * \\
\hline 8 & 2陧A-3工区建方 & $\cdot 17$ & 18 & 17 & 18 & 0 & $*$ \\
\hline 9 & 2陵A-3エ区グラ外 & 20 & 21 & 20 & 21 & 0 & * \\
\hline 10 & 3階A-3エ区デッキ & 18 & 19 & 18 & 19 & 0 & * \\
\hline 11 & 3階A-3工区建方 & 19 & 20 & 19 & 20 & 0 & * \\
\hline 12 & 3階A-3エ区グラ外 & 22 & 23 & 24 & 25 & 2 & \\
\hline 13 & 4嚿Aー3エ区デッキ & 20 & 21 & 20 & 21 & 의 & * \\
\hline 14 & 4階A-3工区建方 & 21 & 22 & 21 & 22 & 0 & * \\
\hline 15 & 4隋A-3工区ゔラ外 & 24 & 25 & 26 & 27) & 2 & \\
\hline 16 & R陼A-3エ区デシキ & 22 & 23 & 24 & 25 & 2 & \\
\hline
\end{tabular}

注1 時間の単位:日

注2 C.P.:クリティカルパス上の作菓に「*」を町入している。

す。ネットワーク図は, 図一 4 の式により休日を含まない連続日で 日程計算を行った結果であり，3.1.節(2)に示したネットワーク表現 の規則に従った最早日程での表示である。各作業の開始日と終了日 は，作業を表すバーの始端上と終端上に表示している。日程計算に 使用した結合率は並行作業への適用箇所を建逃げ工区毎に図下段の 結合率の欗に示しており，それ以外は FS タイプの順序関係である。 また, 最早と最遅の日程, それから求まるトータルフロートとクリ
ティカルパスの計算結果の一部を表ー 2 に示した。

以上より, 次の 2 つを確認した。

(1)結合率を導入したネットワークの表現と日程計算は問題なく 実行できる。

(2) 建方工程を建逃げ工区毎の作業で表すと並行作業の関係が発 生するが, 結合率を適用することでネットワーク手法による詳 細工程計画が可能となる。これより, 建逃げ工区間の順序関係 や工期などの全体的な把握が容易になる。

(3)資源の山積計算

日程計算以外に, 従来のネットワーク手法が提供する機能のひと つに労務・機械などの資源の山積計算がある。

図ー.7の最下段は, 職種別の人数を日毎に集計した結果の表示で ある。山積計算用に新たに必要となるデータは，作業毎に必要とな る職種の人数である。職種別の人数は建方作業を冝工 12 人,デッキ の敷込み作業をデッキエ 4 人, グラウト作業をグラウトエ 4 人, 構 台解体作業を蔦工 12 人とした。以上のデータを利用し, 山積計算は 従来のネットワーク手法に扔けるそれと同様に行う。すなわち, 山 積計算は作業毎に，日程計算で求めた開始日から終了日の期間に対 し, 当該作業が必要とする職種の人数を職種毎かつ日毎に加算する。 図一 7 の最下段は以上のデータと算出方法で求めた山積であり, 結 合率を導入したネットワークにおいても, 従来のネットワーク手法 と同様の山積計算と平準化の検討ができる。 


\subsection{PCa 工法における建方工事の作業計画への適用}

\subsection{1. 適用対象と対象建物の概要}

(1)適用対象の概要

本適用例は，PCa 工法における建方工事の作業計画注8)を対象に， 結合率の適用を検討したものである 7)。検討対象は，建方工事の作 業測定により収集したデータを利用し，結合率による並行作業の表 現とそれをパラメータとした労務の平準化の可能性である。適用対 象の PCa 工法は, 4.1.節の適用例で示した工法と同一の躯体 PCa 工 法である。

(2)対象建物の概要

対象建物は延床面積が約 $47,200 \mathrm{~m}^{2}$, 地下 1 階, 地上 5 階のショッ ピングセンターである。図ー8に工区分割を示す。図ー8-(1)は建 逃げ工区の分割であり，A工区から順に建方を実施した。図－8-(2) に示すように，調査対象とした A I区はさらに 3 つの単位工区に分 割されている。各単位工区は作業区切りの良さを理由に 1 日で完了 する範囲で設定されている。

\subsection{2. 作莱湖定桔果に基づく桔合本の適用}

(1)建方工事の作業測定結果

$\mathrm{A}$ 工区の作業測定の結果, 調查事例として以下の 3 点を把握した。 (1)単位工区は 1 日の作業であり，その作業内容は柱と梁の建方だ けでなく，搬入と HTB 本締めを含む。表一 3 にA-(1)工区の測 定結果を示す。ここで, 各作業のピース数と所要時間から 1 ピ ース当りの所要時間を示した。

(2)作業チームは鉄骨或工 9 名で編成され，作業毎の必要人数は表 - 3 の作業人数に示す通りであった。

(3)A-(1)工区における労務の山積は図ー9-(1)となった。山積は建 方工事の 1 日の作業内容と人数で示した。

(2)結合率による作業計画の表現

調查事例にて並行作業の関係にあるのは, 梁建方と HTB 本締めで ある。柱と梁の建方を 1 作業とする柱・梁建方を先行作業 $\mathrm{i}$ ，これ に続く HTB 本締めを後続作業 j とし, 両作業間の順序関係に結合率 を導入した。結合率を建方作業の所要時間に基づき算出した結果， 調查事例では先行側の結合率 PRij が $87 \%$, 後続側の結合率 SRij が $0 \% に な る 。$

(3)先行側の結合率のとりうる範囲

柱・梁の建方順序は，柱の建方が全て終了後，梁の建方が実施さ れた。HTB 本締めを最も早く開始する場合，作業の開始時間は大梁 1 ピース目の建方を終了した時点となる。すなわち先行側の結合率 の最小值は，柱全数と大梁 1 ピースの所要時間が建方の全所要時間 に占める割合で算出される。

（先行側の結合率 PRij の最小值）

$=\frac{(\text { 柱建方の全所要時間 })+(\text { 大梁建方 } 1 \mathrm{p} \text { の所要時間 })}{\text { 建方の全所要時間 }(\text { 柱, 大梁, 小梁) }}$
$=\frac{130.0+6.3}{130.0+81.9+47.2}=53(\%)$.

一方, 最大值は全ての柱と梁の建方終了後に, HTB 本締めを着手す る場合であり，その結合率は $100 \%$ ある。

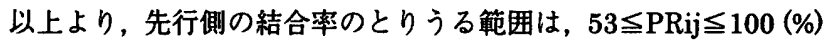
と定義される。
(1) 建逃げ工区の分割

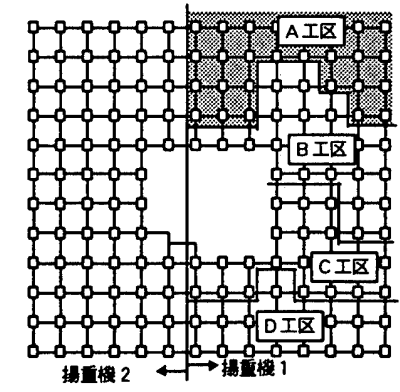

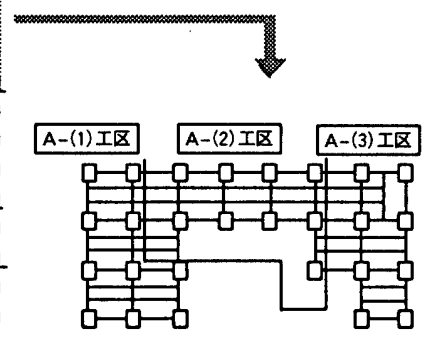

(2)単位工区の分割
図-8 対象建物の工区分割

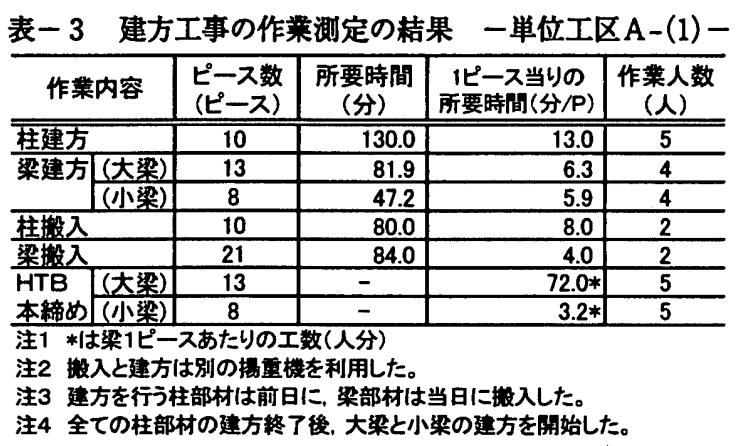

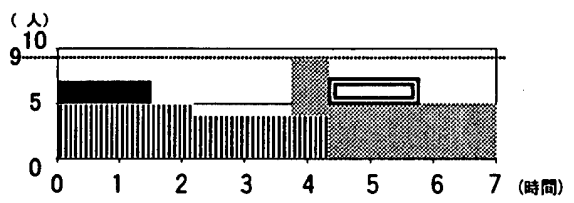

(1)結合率 $\mathrm{PRij}=87 \%$ (調查事例)

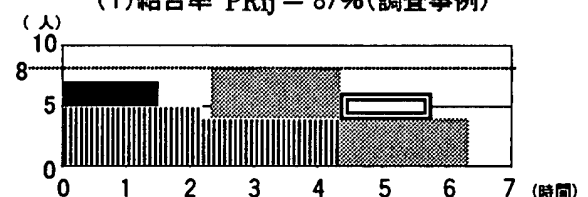

(2) 結合率 PRij $=53 \%$

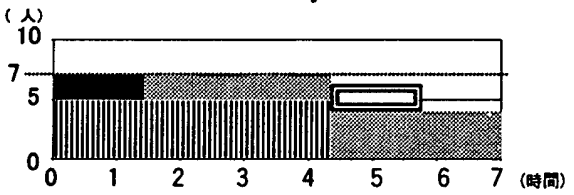

(3) 結合率 PRij $=31 \%$,作業人数の変更

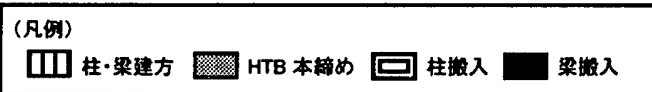

注 後続湖の結合事 SRij は(1)〜(3)とも，0\%である。

図ー9 1 日の作莱内容と人数で示した労務山程

\subsection{3. 桔合索をバラメータとした労務の平準化}

(1)先行側の結合率を最小とした労務の平準化

上述の作業計画において，先行側の結合率を操作することにより 労務の平準化を図ったシミュレーションを実施した。ここで，先行 側の結合率 PRij を最小值である 53 \%とした。これは建方が完了した 梁部材から，直ちにHTB 本締めを開始する計画である。

図-9-(2)に結果の労務山積を示す。HTB 本締め作業を早期に 着手することで，その作業の人数を 4 名で計画でき，チーム人数も 8 名に低隇される。全体の作業時間も短縮された。 
(2)結合率と HTB 本締めの人数をパラメータとした労務の平準化 次に柱・梁の建方順序を変更することで結合率を変更し,かつ HTB 本締めの作業人数を作業の途中から変動させることにより，労務の 平準化を試みた。建方作業は柱 4 本，梁 4 本で囲まれる 1 区画単位 に実施しこれに合わせ HTB 本締めも追いかけて実施する計画とし た。表ー 3 に示した調查事例では柱と梁の建方の人数が異なるが, 本シミュレーションでは柱と梁の建方作業が交互に実施されるため, いずれも 5 名とする。このとき，先頭の 1 区画分の所要時間から， 先行側の結合率 PRij は $31 \%$ となる。さらに HTB 本締めの作業人数 は建方と並行する間を 2 名，建方作業終了後を 4 名で計画した。

結果としてチーム人数を 7 名で計画することができる。図 $-9-$ (3)にこの結果を示す。

\section{5. まとめ}

本報告は作業間の順序関係に結合率を導入したネットワーク手法 を提案するとともに詳細工程計面と作業計画への適用例を示した。 本手法はサークル型ネットワークを対象にするものであり，並行作 業を表現する上でグラフ理論的に問題がなく，既存の分岐ネットワ 一クと異なる基礎的手法である。得られた知見を以下に示す。

(1)作業間の順序関係に結合率を導入したネットワーク表現を示した。 その考え方と特徴は以下の 6 つとなる。

(1)結合率は先行作業と後続作業の各々の所要期間に対する作業が

経過した割合(\%)であり，先行側と後続側の結合率で定義する。

(2)結合率を作業間の順序関係に導入すると，後続作業が後続側の 結合率だけ経過する時刻は，先行作業が先行側の結合率だけ経 過する時刻以後となる。

(3)結合率を導入したネットワーク表現の規則は次の 2 つである。 1)ノードであるバーの長さは作業の所要時間を表す。 2)作業の順序関係を示すアローは結合率により，アローの始端 となる先行側ノードの接続点と終端となる後続側ノードの接 続点を結ぶ。

(4)分岐ネットワークとの違いは，1)サークル型ネットワークの探 用，2)リードタイムという時間でなく，結合率という割合によ る並行作業の表現である。

(5)利用頻度の高い並行作業の表現は，先行作業または後続作業の 一方を基準とした結合率の設定になる。

(6)結合率は一般的な 4 タイプの作業間の順序関係を包含するもの であり，結合率が特殊な場合としてその 4 タイブを表せる。

(2)結合率を導入したネットワークの日程計算を定式化した。

(1)定式化は, 最早と最遅の日程計算に使用する式を示した。

(2)従来のネットワーク手法における日程計算との違いは，先行作

業と後続作業の所要期間に，それぞれ先行側と後続側の結合率 を乗じることなどである。

(3)躯体 PCa 工法の建方工事における詳細工程計画と作業計画を対

象に，本手法の適用可能性を確認した。

(1)詳細工程計画への適用では，次の 2 つを確認した。

1)結合率を導入したネットワークの表現と日程計算は問題なく 実行できる。

2)建方工程を建逃げ工区毎の作業で表すと並行作業の関係が発 生するが，結合率を適用したネットワークとすることで建逃
げ工区間の順序関係や工期などの全体的な把握が容易となる。 (2)作業計画への適用では作業測定により収集したデータを利用し， 結合率をパラメータとしたシミュレーションを行った。その結 果, 以下の 2 つを確認した。

1)並行作業の関係を結合率のとりうる範聿で定量化できる。 2)結合率は労務の平準化のパラメータとして有効である。 今後の課題は，1)本手法の適用範囲の把旺, 2)進渉管理段階での活 用方法の検討などである。

\section{参考文献}

1)日本建築学会：“ネットワークによる工程の計画と管理”の指針 同解説, 日本建築学会, 1968 年

2)嘉納成男：我が国の建筑生産をめぐる管理活動はどこまで准歩したか 工程 の管理，第 7 回建築生産と管理技術 PD 報文集(1996 年), pp.67-72

3)嘉納成男：建貿工事の工程計画に関する研究（その 3 ）詳細工程計画手法の 開発，日本建等学会計画系論文報告集，No.423，pp.59-68，1991 年 5 月 4)森口五郎, 若木俊男 : 建築工事における基本工程表作成手法に関する研究, 日本建筑学会計画系論文報告集, No.445, pp.121-131，1993 年 3 月 5)土㛢棇美, 吉田知洋, 山田辰雄 : 作業間の順序関係に結合率を導入したネッ トワーク手法そその 1 結合率を導入したネットワークの定式化, 日本建築 学会大会学術講演梗概集（中国），pp.1141・1142，1999 年 9 月

6)土㛢稳美, 正村芳久, 吉田知洋: PCa 工法における建方計画の支嗳手法 そ の2 建方工程における並行作業のモデル化, 日本建筑学会大会学術講演梗 概集（東北），pp.1313·1314，2000 年 9 月

7)吉田知洋, 土橋稳美, 山田辰雄: 作業間の順序関係に結合率を導入したネッ トワーク手法 その 2 プレキャスト工法における建方工事の作業計画へ の適用, 日本建筑学会大会学術講演梗概集（中国），pp.1143.1144，1999 年. 9 月

8) プロジェクト・マネジメント部会：プロジェクトマネジメントの基碳知識体 系(Pmbok guide 和訳版)、エンジニアリンク掁興協会, 1997 年 3 月

\section{注}

注1）文献 1)では工程計画を手順計画と日程計画に分けて示しているが，プロ ジェクトの計画全体の中で施工方法，㗄源配分計画，資機材の搬入・揚 重などを総合的に検討し、ネットワーク工程に表現する必要があること も指摘している。贺納による工程管理技術の変逥を示した文献 2)におい ても，同様の指摘がなされている。

注2)アロー型ネットワークは作業をアローで示したネットワーク図のことで ある（文献 1））。建築工事向けに開発・販売されてきた日程計画用の 国内のソフトウェアはアロー型ネットワークを探用するものが多い。

注3)サークル型ネットワークは作業をサークル（ノード）で，作業間の順序関 係をアローで示したネットワーク図のことである（文献 1））。サーク ル型ネットワークは作業の順序関係の検討に利用されるだけでなく，サ ークルをバーとし，バーの長さを作業の所要期間で表すことで日程計面 でも活用される。米国 PMI(Project Management Institute)が発行した プロジェクトマネジメント解説書の和訳版（文献 8））によると,サー クル型ネットワークをブレシデンスタイアグラムと呼んでいる。

注4)不等号がつく理由は図ー1-(1)の一般的な4タイブと同様に, 先行作業が 複数になることもあるためである。

注5)文献 8)では, 先行作業を基準とした設定により発生するオーバラップ期 間をリードタイムと呼んでいる。

注6)タイムラグは, 先行作業の終了時刻からどの程度達れて後絖作業を開始す るかを表すものである。

注7)本報告における詳細工程計画は職種または尃門工事業每に作業を捉え，手 順計画と日程計画を実施することである。時間軸は「日」単位である。

注8)本報告における作業計画は詳細工程計画の析組みの中で, 作業チームの編 成と各作業チームの作業の手順と日程を計面する意味で用いる。ここで の日程計画は「時」単位程度の時間割表のことである。

（2000年 9 月 1 日原稿受理，2000年 10 月 31 日採用決定） 